\title{
AKTIVITAS INFUSA DAUN TAPAK DARA (CATHARANTHUS ROSEUS L.) TERHADAP PENURUNAN KADAR GLUKOSA DARAH TIKUS PUTIH (RATTUS NORVEGICUS)
}

\author{
Yuli Permatasari, Lizma Febrina, Arsyik Ibrahim \\ Laboratorium Penelitian dan Pengembangan FARMAKA TROPIS Fakultas Farmasi Universitas \\ Mulawarman, Samarinda, Kalimantan Timur \\ email:day_li2@yahoo.com
}

\begin{abstract}
ABSTRAK
Penelitian ini bertujuan untuk mengetahui aktivitas infusa daun tapak dara (Catharanthus roseus L.) terhadap penurunan kadar glukosa darah pada tikus putih. Penelitian ini merupakan desain eksperimental laboratorium dengan menggunakan tikus putih sebanyak 15 ekor yang diinduksi aloksan $120 \mathrm{mg} / \mathrm{kgBB}$ setiap dua hari sekali secara intraperitonial. Tikus dibagi menjadi lima kelompok, antara lain kelompok kontrol negatif (Aquades), kelompok kontrol positif (Glibenklamid), serta kelompok uji yang diberikan infusa daun tapak dara 25\%, 45\% dan 65\%. Data hasil penurunan kadar glukosa darah dianalisis dengan menggunakan uji ANOVA dua arah dan terdapat perbedaan yang sangat signifikan antar kelompok uji sehingga dilanjutkan dengan uji Beda Nyata Jujur Duncan (BNJD). Hasil penelitian menunjukkan infusa daun tapak dara pada konsentrasi $25 \%$, 45\% dan 65\% memberikan aktivitas terhadap penurunan kadar glukosa darah pada tikus putih.
\end{abstract}

Kata kunci: Infusa daun tapak dara, tikus putih, glukosa darah, aloksan

\begin{abstract}
The research aimed was to obtain the activity of tapak dara leaves infuse (Catharanthus roseus $L$.) on the effect decreasing blood glucose level on white rats. This research was a experimental laboratory design using 15 white rats induced $120 \mathrm{mg} / \mathrm{kgBB}$ alloxan once in every two days by intraperitoneal. The rats being divided into 5 groups, which are negative control group (Aquades), positive control group (Glibenklamid), and concentration 25\%, $45 \%$ and $65 \%$ groups of infuse of tapak dara leaves. The data of decreasing blood glucose level were analyzed by two-way ANOVA which there were significance differences between all groups, so proceed with BNJD test. The results showed that infuse of tapak dara leaves in concentration 25\%, 45\% and 65\% have effect in decreasing blood glucose level on white rats.
\end{abstract}

Keywords: Infuse of tapak dara leaves, white rats, blood glucose, alloxan

\section{PENDAHULUAN}

Sejak awal abad ini, Indonesia telah menjadi negara dengan jumlah penderita diabetes mellitus terbanyak ke-4 di dunia, setelah Amerika Serikat, India dan China (Suyono, 2005). Keadaan ini diperkirakan akan terus meningkat dikarenakan gaya hidup yang kurang baik, terutama di negara berkembang. Diabetes mellitus merupakan suatu kelompok penyakit metabolik dengan karakterisrik hiperglikemia yang terjadi karena kelainan sekeresi insulin, kerja insulin, atau kedua-duanya (Misnadiarly, 2006). 
Eksplorasi tanaman asli Indonesia sebagai agen fitofarmaka terus digalakkan. Lebih dari 400 tanaman dilaporkan digunakan secara empiris untuk mengobati diabetes (Subroto, 2006). Salah satunya yaitu tapak dara (Catharanthus roseus L.) yang selama ini dianggap sebagai bunga liar dan murahan, namun sekarang mulai ditanam sebagai tanaman hias pekarangan.

Tanaman tapak dara banyak diteliti untuk mengobati berbagai penyakit. Dekokta daun dan tanaman utuh digunakan sebagai obat diabetes di beberapa negara antara lain Brazil, Inggris, Pakistan, Taiwan (Sutrisna, 2012).Tapak dara juga secara tradisional digunakan untuk pengobatan penyakit malaria, sembelit, diuretika, diabetes melitus, hipertensi dan hiperkolesterol (Dharma, 2013). Dalam beberapa literatur tanaman obat, untuk mengobati pentakit diabetes digunakan rebusan daun segar tapak dara.

Dengan demikian peneliti tertarik untuk meneliti potensi daun tapak dara dalam mengobati penyakit diabetes, maka akan dilakukan pengujian aktivitas infusa daun tapak dara (Catharanthus roseus L.) terhadap penurunan kadar glukosa darah pada tikus putih (Rattus norvegicus) yang diinduksi aloksan.

\section{METODE PENELITIAN}

\section{Alat dan Bahan}

Alat yang digunakan dalam penelitian ini adalah panci infus, alat-alat gelas laboratorium, saringan/kain saring, Glukometer, neraca analitik, neraca hewan, pisau atau gunting, sonde oral, spoid, dan penangas/kompor.

Bahan yang digunakan dalam penelitian ini adalah aloksan, $\mathrm{NaCl} 0,9 \%$, aquades, daun tapak dara (Catharanthus roseus L.), glibenklamid, Glucotest strip test, kertas saring, alkohol, kapas, rivanol dan $\mathrm{Na} \mathrm{CMC}$.

Hewan percobaan yang digunakan adalah tikus putih jantan berumur \pm 3 bulan dengan berat 170-250 gram dan sehat.

\section{Prosedur}

Bahan yang diuji dalam penelitian ini adalah daun tapak dara (Catharanthus roseus L.) yang dibuat dalam bentuk infusa. Daun tapak dara diperoleh dalam keadaan segar ditimbang, kemudian dicuci bersih dan dipotong kecil-kecil. Kemudian dimasukkan dalam panci infus, ditambahkan aquades dengan volume tertentu dan direbus dengan suhu $90^{\circ} \mathrm{C}$ selama 15 menit. Lalu disaring dan residu yang dihasilkan dikeringkan. Dihitung konsentrasi infusa yang dibuat.

Tikus putih jantan sebanyak 13 ekor diadaptasikan dahulu di Laboratorium Penelitian Farmaka Tropis Fakultas Farmasi selama 2 minggu dan diberi makan pelet dan minum aquades. Tikus dibagi dalam 5 kelompok, tiap kelompok terdiri atas 3 ekor tikus, masing-masing kelompok terdiri atas: 1) Kelompok kontrol negatif: diberikan aquades, 2) Kelompok kontrol positif: diberikan obat glibenklamid 0,09 mg/200 gBB, 3) Kelompok uji I: diberikan infusa daun tapak dara $25 \%$,4) Kelompok uji II: diberikan infusa daun tapak dara $45 \%, 5)$ Kelompok uji III: diberikan infusa daun tapak dara 65\%. Sebelum perlakuan tikus dipuasakan selama 16 jam namun tetap diberi minum, kemudian diperiksa kadar glukosa darah puasanya dengan menggunakan Glukometer.

Kemudian semua tikus diinduksi aloksan $120 \mathrm{mg} / \mathrm{kgBB}$ secara intraperitoneal setiap 2 hari sekali hingga kadar glukosa darah tikus masuk dalam rentang kadar diabetes (>200 $\mathrm{mg} / \mathrm{mL}$ ) sehingga diperiksa kadar glukosa tikus sehari setelah pemberian aloksan. Hari dimana kadar glukosa darah tikus telah naik (>200 mg/mL) merupakan hari ke-1. Kemudian diberikan perlakuan (kontrol dan uji) pada hewan coba yang dilakukan pada hari ke-1 sampai dengan hari ke-7 dan pengukuran kadar glukosa darah dilakukan pada 
hari ke-1 hingga ke-8. Pengambilan darah dilakukan pada pembuluh darah ekor hewan coba.

Untuk analisis data, parameter yang digunakan adalah penurunan kadar glukosa darah dari hari ke-2 sampai hari ke-8 dari keempat kelompok perlakuan dianalisis dengan uji ANOVA dua arah pada tingkat kepercayaan 95\% dan 99\%. Apabila hasil uji ANOVA menunjukkan adanya perbedaan bermakna, maka dilanjutkan dengan uji lanjutan.

\section{HASIL DAN PEMBAHASAN}

Konsentrasi infusa daun tapak dara ditentukan dari berat daun segar dikurangi dengan berat residu daun yang dikeringkan dan dibagi dengan volume infusa yang dihasilkan. Dari $14 \mathrm{~g}$ daun tapak dara segar yang direbus dalam $60 \mathrm{~mL}$ aquades selama 15 menit pada suhu $90{ }^{\circ} \mathrm{C}$ menghasilkan infusa dengan volume $25 \mathrm{~mL}$ dan residu daun yang dikeringkan sebanyak 2,5 g, sehingga diperoleh konsentrasi infusa 45\% (13,25-2,5 g/25 $\mathrm{mL})$.

Pengukuran kadar glukosa darah yang dilakukan pada hari ke-1 hingga hari ke-8 setelah pemberian perlakuan (kontrol dan uji) bertujuan untuk mengetahui perubahan kadar glukosa darah yang dihasilkan oleh masing-masing kelompok kontrol dan uji. Pada Gambar.1 terlihat kadar glukosa darah tikus pada kelompok kontrol positif dan kelompok uji infusa konsentrasi 25\%, 45\% dan 65\% mengalami penurunan sedangkan pada kelompok kontrol negatif penurunan kadar glukosa darah tidak berarti.

Untuk mengetahui aktivitas infusa daun tapak dara terhadap penurunan kadar glukosa darah tikus putih, maka data yang akan dibandingkan adalah penurunan kadar glukosa dari hari ke-2 sampai dengan hari ke-8 pada kelompok kontrol negatif dan uji. Rerata penurunan kadar glukosa darah menujukkan bahwa kelompok uji kensentrasi infusa $25 \%$, 45\% dan 65\% memiliki aktivitas terhadap penurunan kadar glukosa darah tikus putih, sedangkan pada kontrol negatif penurunan kadar glukosa darah tidak berarti. Tabel 1. menunjukkan bahwa uji Anava dua arah pada tingkat kepercayaan 95\% dan 99\% memberikan hasil sangat signifikan dimana Fhitung > Ftabel, yang berarti ada perbedaan bermakna antara kelompok perlakuan uji dan kontrol negatif pada penurunan kadar glukosa darah tikus putih. Dengan demikian, dilakukan uji lanjutan berdasarkan nilai Koefisien Keseragaman (KK) yaitu uji Beda Nyata Jujur Duncan (BNJD).

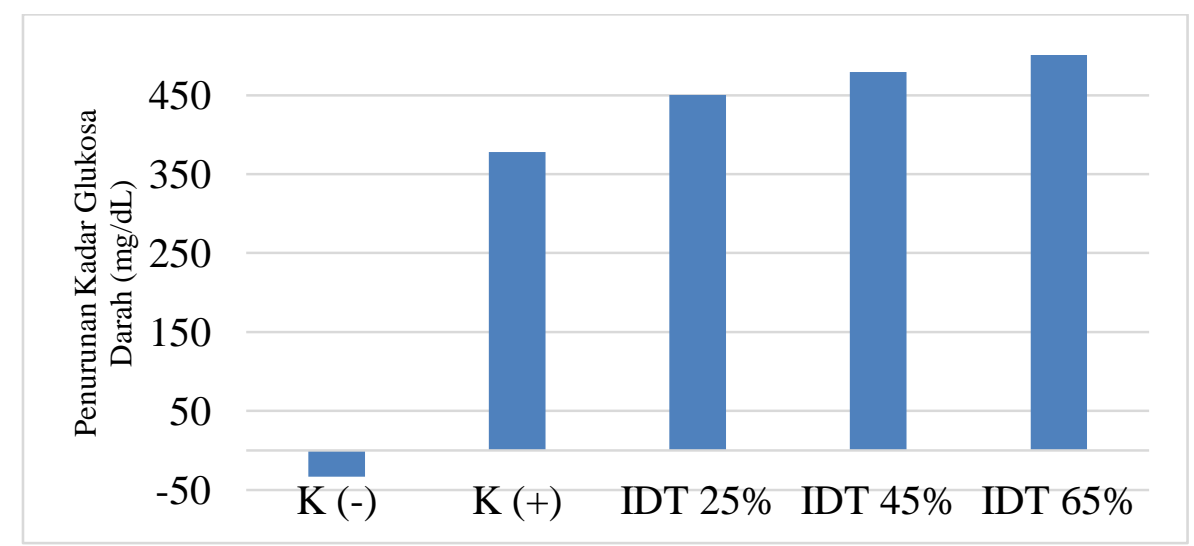

Keterangan $: I D T=$ Infusa Daun Tapak Dara

Gambar 1. Grafik Rerata Penurunan Kadar Glukosa Darah Tikus Putih 
Tabel 1. Hasil Analisis Anova Dua Arah

\begin{tabular}{lrrrrrr}
\hline \multicolumn{1}{c}{$\begin{array}{c}\text { Sumber } \\
\text { Variansi }\end{array}$} & \multirow{2}{*}{ Db } & \multirow{2}{*}{ JK } & \multirow{2}{*}{ KT } & \multirow{2}{*}{ Fhitung } & \multicolumn{2}{c}{ F Tabel } \\
\cline { 5 - 7 } & & & & $\mathbf{5 \%}$ & $\mathbf{1 \%}$ \\
\hline Konsentrasi Uji & 3 & 72792,024 & 24264,008 & $3,547^{*}$ & 2,77 & 4,15 \\
Waktu & 6 & 183156,810 & 30526,135 & $4,462^{* *}$ & 2,27 & 3,14 \\
Interaksi & 18 & 538859,976 & 29936,665 & $4,376^{* *}$ & 1,81 & 2,32 \\
Galat & 56 & 383124,000 & 6841,500 & & & \\
\hline Total & 83 & 1177932,810 & & & & \\
\hline
\end{tabular}

Keterangan :

* Signifikan

** Sangat signifikan

Tabel 2. Perbedaan Nilai Rerata Penurunan Kadar Glukosa Darah Hewan Coba antar Kelompok dari Hasil Uji BNJD

\begin{tabular}{rrrccc}
\hline \multirow{2}{*}{ No. } & \multirow{2}{*}{ Perlakuan } & \multirow{2}{*}{ Rerata } & Negatif & $\mathbf{2 5 \%}$ & $\mathbf{4 5 \%}$ \\
\cline { 4 - 6 } & & $|33,429|$ & 431,000 & 479,571 \\
\hline 1 & Negatif & $|33,429|$ & - & & \\
2 & $25 \%$ & 431,000 & $397,571 * *$ & - & \\
3 & $45 \%$ & 479,571 & $446,142^{* *}$ & 48,571 & - \\
4 & $65 \%$ & 557,429 & $524,000 * *$ & 126,429 & 77,858 \\
\hline & $\mathrm{p}(0,05.56)$ & 2,843 & 2,991 & 3,087 \\
& BNJD 0,05(p.Sy) & $\mathbf{1 3 5 , 7 6 7}$ & $\mathbf{1 4 2 , 8 3 5}$ & $\mathbf{1 4 7 , 4 2 0}$ \\
\hline & $\mathrm{p}(0,01.56)$ & 3,793 & 3,955 & 4,064 \\
& BNJD 0,01(p.Sy) & $\mathbf{1 8 1 , \mathbf { 1 3 5 }}$ & $\mathbf{1 8 8 , 8 7 1}$ & $\mathbf{1 9 4 , 0 7 6}$ \\
\hline
\end{tabular}

Keterangan :

** Sangat signifikan

Hasil uji lanjutan BNJD pada Tabel 2. menunjukkan bahwa antara kelompok kontrol negatif dengan kelompok uji infusa 25\%, 45\% dan 65\% sangat signifikan yang berarti terdapat perbedaan bermakna penurunan kadar glukosa darah. Antara kelompok uji infusa $25 \%$, 45\% dan $65 \%$ tidak signifikan yang berarti tidak terdapat perbedaan bermakna penurunan kadar glukosa darah. Akan tetapi, dilihat dari rerata penurunan kadar glukosa darah kelompok uji infusa dengan konsentrasi 65\% lebih baik dibandingkan kelompok konsentrasi uji $25 \%$ dan $45 \%$ karena nilai rerata yang lebih besar. Jadi, infusa daun tapak dara konsentrasi $65 \%$ lebih baik dibandingkan dengan infusa daun tapak dara konsentrasi $25 \%$ dan $45 \%$ dalam menurunkan kadar glukosa darah tikus putih yang diinduksi aloksan.

Aloksan dapat menghasilkan radikal hidroksil yang sangat reaktif dan dapat menyebabkan diabetes pada hewan coba. Efek diabetogenik aloksan ini dapat dicegah oleh senyawa penangkap radikal hidroksil (Studiawan, 2005). Salah satu senyawa dalam kandungan daun tapak dara yang diduga mempunyai kemampuan menurunkan kadar glukosa darah adalah flavonoid terutama kuersetin. Flavonoid secara umum diduga memiliki kemampuan meregenerasi dan merangsang pelepasan insulin pada sel Betapankreas (Sutrisna, 2012). 


\section{KESIMPULAN}

Infusa daun tapak dara dengan konsentrasi $25 \%, 45 \%$ dan $65 \%$ memiliki aktivitas terhadap penurunan kadar glukosa darah tikus putih yang diinduksi aloksan, dimana infusa dengan konsentrasi 65\% lebih baik dibandingkan dengan konsentrasi $25 \%$ dan $45 \%$.

\section{DAFTAR PUSTAKA}

Dharma, Surya. 2013. Uji Efek Ekstrak Etanol Daun Tapak Dara (Catharantus roseus L) Terhadap Kadar Kolesterol Total Darah. Mencit Putih Jantan. Prosiding Seminar Nasional Perkembangan Terkini Sains Farmasi dan Klinik III 2013.

Misnadiarly. 2006. Diabetes Mellitus:Ulcer, Gangren, Infeksi. Pustaka Populer Obor: Jakarta.

Suyono, Slamet. 2005. Kecenderungan Peningkatan Jumlah Penyandang Diabetes Mellitus. Dalam: Penatalaksanaan Diabetes Mellitus Terpadu. FKUI: Jakarta.

Subroto, A. 2006. Ramuan Herbal untuk Diabetes Melitus. Penebar Swadaya: Jakarta.

Studiawan, Herra dan Mulja Hadi Santosa. 2005. Uji Aktivitas Penurunan Kadar Glukosa Darah Ekstrak Daun Eugenia polyantha pada Mencit yang Diinduksi Aloksan. Media Kedokteran Hewan. 21. (2). Halaman 64.

Sutrisna, EM, Sahila Ermawati, Mulyadin dan Mios Agung. 2012. Uji Praklinis Efek Hipoglikemik Blimbing Wuluh (Averrhoa bilimbi L.) dan Daun Tapak Dara (Catharanthus roseus G). Jurnal Pharmacon.13. (1). Halaman 39. 